\title{
Development of Conversational Skills from Late Children to Adolescent
}

\author{
Yewon Yang, ${ }^{\mathrm{a}}$, YoonKyoung Lee ${ }^{\mathrm{b}}$, Jieun Choi ${ }^{\mathrm{c}}$, Ji Hye Yoon ${ }^{\mathrm{b}}$ \\ ${ }^{a}$ Department of Speech Pathology, Graduate School of Health Sciences, Hallym University, Chuncheon, Korea \\ ${ }^{b}$ Division of Speech Pathology and Audiology, Hallym University, Chuncheon, Korea \\ 'Department of Speech-Language Pathology and Audiology, Graduate School of Hallym University, Chuncheon, Korea
}

\author{
Correspondence: YoonKyoung Lee, $\mathrm{PhD}$ \\ Division of Speech Pathology and Audiology, \\ Hallym University, 1 Hallimdaehak-gil, Chuncheon \\ 24252, Korea \\ Tel: +82-33-248-2219 \\ Fax: +82-33-256-3420 \\ E-mail: ylee@hallym.ac.kr
}

Received: January 5, 2018

Revised: June 6, 2018

Accepted: June 6, 2018

This work is based on a partial data from the first author's master thesis.

This work was supported by the Hallym Leading Research Group Support Program of 2017 (No. HRF-LGR-2017-0002)

\begin{abstract}
Objectives: This study aimed to examine developmental differences in conversational skills from childhood to adolescents. Methods: A total of 45 students were participated in the study. Fifteen students were in the higher grade of elementary school, 15 were in middle school and 15 were high school students. Conversation samples were collected by the examiner through the Hallym Conversation \& Pragmatic Assessment Protocol. The number of turn-taking, frequency of utterances per turn, the total number of topics, frequency of turns per topic, rates of initiation, maintenance, and change were measured. Results: The results revealed a significant difference in the total number of topics, frequency of turns per topic the rates of initiation, maintenance, and change excluding utterance per turn. Conclusion: The results of the study show that conversational skills develop continuously during late childhood and adolescents. These help us further understanding of conversational skills in adolescent periods.
\end{abstract}

Keywords: Adolescent, Conversational development, Topic manipulation
인간은 대화를 통해서 사람들과 정보를 공유하고 친밀한 유대관 계를 쌓는다. 대화란 두 사람 이상이 마주 대하여 이야기를 주고받 는 기본적인 양방향 의사소통으로, 원활한 의사소통을 하기 위해 서는 상대방에게 자신의 감정을 잘 전달해야 하며 숙달된 대화 기 술이 필요하다. 대화에는 여러 언어적 기술이 요구되나 그 중 대화 차례 주고받기 능력과 주제 관리 능력은 주요 대화적 기술로 고려 된다(Brinton \& Fujiki, 1984; Heo \& Lee, 2012).

대화차례 주고받기 기술은 상대방과의 대화하는 상황에서 화자 와 청자가 서로 말을 주고받는 것이다. 적절한 대화를 위해서는 맥 락에 맞게 대화를 개시해야 하고 상대방이 말을 하는 동안에는 발 화를 중첩하여 산출하지 않아야 하며, 대화 상황에 따라 서로의 대 화차례가 달라질 수 있다는 것을 알아야 한다(Sacks, Schegloff, \& Jefferson, 1974). 이와 더불어 대화 상황에 적절하게 대화 주제를 다 루는 대화 주제 관리 기술이 중요하다. 주제 관리 능력이란 문맥과 상황에 따라 적절하게 주제를 다룰 수 있는 능력을 말하며, 적절한 시기에 주제를 소개하고 이전의 대화 흐름에 따라주제를 유지해나
가며 자연스럽게 새로운 주제로 변경하는 것이 주제 관리에서 중요 하다. 따라서 상대방과의 자연스러운 대화를 위해 필요한 요소는 적절하게 대화를 주고받는 대화차례 주고받기와 상황에 맞게 주제 를 개시하고 이전의 주제에 벗어나지 않도록 주제를 자연스럽게 유 지, 변경해나가는 주제 관리 능력으로 구성되어 있다.

일반적으로 대화차례 주고받기 기술은 아주 어린 영아기부터 발 달하며 비교적 이른 시기에 습득되는 반면, 대화 주제를 관리하는 능력은 아동기 이후 시기까지도 지속적으로 발달하는 것으로 알려 져 있다(Nippold, 2007). 연령이 증가할수록 대화주제 관리 능력이 발달하면서 한 주제로 더 길게 대화를 유지할 수 있고, 한 주제에서 다른 주제로 자연스러운 변경이 가능하게 된다(Park, Choi, \& Lee, 2017). 또한 대화차례를 주고받는 길이가 더 길어지고, 주제를 다루 는 능력이 발달하면서 주제를 유지, 확장, 변경하는 능력 등을 키워 대화능력이 더욱 정교화된다(Park et al., 2017). 초등학생의 대화 주제 관리 발달을 살펴본 Park 등(2017)은 학년이 올라갈수록 대화 안에서 주제 수가 적어지고 한 주제 안에서 주제를 일관적으로 유 
지해나가는 능력이 발달된다고 하였다. Schley와 Snow (1992)도 9 세에서 12 세로 연령이 증가하면서 단순한 예, 아니오 대답이 감소 하면서 주제유지 비율이 증가했다고 보고하였다. 이와 같이, 학령 기에 연령이 증가할수록 주제 관리 능력은 점진적으로 발달한다는 것을 보여준다.

대화 기술은 아동기 이후까지도 매우 중요하다. 청소년기 또한 교 실상황 및 또래와의 환경이 일상생활에서 많은 부분을 차지하므로 변화된 환경에 적응하여 효율적인 의사소통을 하기 위해서는 대화 의 기술을 고급화하며 발달한다고 볼 수 있다(Brinton \& Fujiki, 1984). 청소년기에 대화를 통해 또래 관계를 형성함과 동시에 대화 능력이 학업성취능력에 영향을 미치고(Loban, 1976) 사회성 발달 에도 중요한 역할(Dodge, 1983)을 한다는 점에서 청소년기의 대화 발달에 대한 지속적인 연구가 필요하다. 의사소통에서 대화의 중요 성이 강조됨에 따라 대화 연구가 활발하게 이루어지고 있지만, 주 로 아동기에 국한되어있다. 본 연구는 아동기 이후 청소년기 대화 발달을 대화 참여와 대화 주제 관리 두 가지 측면으로 나누어 살펴 보고자하였다.

\section{연구방법}

\section{연구대상}

본 연구에는 강원, 경기, 서울 지역의 초등 고학년생 15 명(남 3 , 여 $12)$, 중학생 15 명(남 5, 여 10$)$, 고등학생 15 명(남 10, 여 5), 총 45 명이 참가하였다.

대상자들은 모두 (1) 신체적, 정서적, 운동 및 감각 등의 발달이 정상적으로 이루어졌다고 보고되었으며, (2) 만 18세 미만은 수용. 표현어휘력검사(Receptive \& Expressive Vocabulary Test, REVT; Kim, Hong, Kim, Jang, \& Lee, 2009)에서 표준편차 -1 SD부터 +2 $\mathrm{SD}$ 사이에 있는 아동 및 청소년으로 하였다. 단, 일부 18 세 이상의 고등학생들의 경우, 국내에서 언어능력을 평가하는 언어검사가 없 으므로 언어능력을 확인하기 위해 한국판 웩슬러 아동용 지능검 사4판(Korean-Wechsler Intelligence Scale for Children-IV; Kwak, Oh, \& Kim, 2011) 소검사 중 언어능력을 반영하는 '어휘'와 ‘이해' 문항을 사용하였다. K-WISC-IV에서 수용언어능력과 표현언어능 력과 높은 상관을 보인 ‘어휘'와 ‘이해’ 문항 결과, 각 항목에서 -1SD 부터 $+2 \mathrm{SD}$ 사이에 있는 청소년들로 선정하였다. 모든 아동 및 청소 년, 부모님들에게 검사 실시 전에 동의서를 얻은 후 진행하였다. 연 구대상자의 생활연령 및 각 검사별 평균과 표준편차는 Table 1과 같다.
Table 1. Participants' information

\begin{tabular}{lccc}
\hline & $\begin{array}{c}\text { Elementary school } \\
(\mathrm{N}=15)\end{array}$ & $\begin{array}{c}\text { Middle school } \\
(\mathrm{N}=15)\end{array}$ & $\begin{array}{c}\text { High school } \\
(\mathrm{N}=15)\end{array}$ \\
\hline $\begin{array}{l}\text { Chronological age }(\mathrm{mo}) \\
\text { REVT }\end{array}$ & $138.33(7.77)$ & $167.93(8.28)$ & $216.00(14.82)$ \\
$\quad$ RLA & $163.20(9.93)$ & $190.44(4.22)$ & $192.00(.00)^{\mathrm{a}}$ \\
ELA & $162.40(12.72)$ & $191.20(3.09)$ & $192.00(.00)^{\mathrm{a}}$ \\
K-WISC-IV & & & \\
$\quad$ Vocabulary & - & - & $11.8(1.3)^{\mathrm{b}}$ \\
Comprehension score & - & - & $11.3(1.5)^{\mathrm{b}}$ \\
\hline
\end{tabular}

Values are presented as mean (SD).

REVT = Receptive \& Expressive Vocabulary Test (Kim, Hong, Kim, Jang, \& Lee, 2009); $R L A=$ receptive language age; $E L A=$ expressive language age.

${ }^{a}$ is a score below 17 years old.

${ }^{b}$ is a score of 18 years or older.

\section{자료 수집 도구 및 절차}

대상자의 발화를 자연스레 유도하기 위해 검사자와 1:1로 대화 를 진행하였다. 자료 수집 도구로는 '한림대화·화용 평가 프로토콜 (Park et al., 2017)'을 사용하여 대상자에게 익숙할만한 '가정생활', '학교생활', '기타/친구’의 주제로 하였고, 각각의 주제별로 3가지의 소주제 질문을 준비하였다. 가정생활과 학교생활은 주제와 관련된 사진을 4장씩 주제별로 봉투에 담아 준비하여 대상자가 게시할 기 회를 제공하였고, '기타/친구'는 사진을 제시하지 않고 검사자가 구 어로 주제를 개시하였다. 사진의 크기는 가로 $100 \mathrm{~mm}$, 세로 $85 \mathrm{~mm}$ 였다. 대화자료는 다음과 같은 절차로 수집하였다.

먼저 대상자와 원만한 대화를 위하여, 라포형성을 위한 대화로 시작하였다. 이후, 대상자에게 진행절차를 설명해주었다. 대상자가 절차를 숙지하였다고 판단되면, '가정생활'과 ‘학교생활'의 그림카 드가 들어있는 두 장의 같은 모양의 봉투를 제시하여 하나를 선택 하게 하였고, 대상자가 선택한 봉투에서 그림카드를 꺼내 대상자의 앞에 무작위로 펼쳐보게 하였다. 대상자가 자발적으로 대화를 이 어나가는 경우, 검사자는 새로운 질문이나 주제를 첨가하지 않고 대상자의 발화에 “응, 그래, 그렇구나"와 같은 중립적인 반응으로 호응해주었다. 검사자가 준비한 세 개의 소주제 중 대상자가 자발적 으로 주제를 개시하지 않은 내용은 질문으로 제공하였다. 대화를 하던 도중 3 초 쉼이 있는 경우에 대상자의 발화를 반복해주었고, 그림자료를 제공한 후에 먼저 발화를 이어나가지 못할 때는 "OO 아, 가족생활은 어때?”라고 이전 주제에 대해 언급해주었다. 언급 해주어도 반응이 없는 경우, “가족끼리 여행가서 뭐해?”와 같은 소 주제 질문을 하였다. 대상자가 대화 도중 발화를 이어나가지 못 할 경우, 검사자는 “그리고?”, “또?”와 같이 촉진하여 대화를 지속적 으로 이어나가도록 하였다. 검사자가 발화를 촉진해주어도 더 이상 
할 말이 없다는 행동을 보이면 다음 소주제로 질문하고, 세 개의 소 주제가 모두 종결된 후 다음 화제를 선택하게 하여 앞의 절차로 대 화를 진행하였다. 준비된 두 개의 주제에 대해 이야기 한 후에는 추 가적으로 '기타/친구'라는 주제로 사진 자료 없이 세 개의 소주제로 질문을 하여 대화를 이어나갔다. 대화 방식은 이전과 마찬가지로 진행한다. 모든 소주제가 종결되었을 때 대상자에게 알림으로 절 차를 마쳤다.

\section{자료 전사 및 자료 분석}

자료전사

대화 자료는 모두 녹음기를 사용해 녹음전용 MP3 (SONY ICDUX533F)로 녹음하였으며, 수집된 자료는 일주일 이내 전사하였다. 발화가 명료하지 않거나 불완전해 맥락을 활용하여도 이해할 수 없는 발화, 아동이 말하는 동안 연구자가 개입해 중첩된 발화, 혹은 혼잣말이나 숫자세기, 호칭과 같이 화용 특성으로 분류되지 않는 발화가 들어간 것은 전사자료에서 제외하였다(Kim \& Lee, 2007).

\section{자료분석}

대화 자료는 대화프로토콜이 완료된 대상자 중, 10 분 이상의 대 화를 실시한 대상자의 자료들로 선정하여 분석을 실시하였다. 분석 을 위해 전사된 자료는 대화차례와 발화로 구분하였다. 대화차례 는 Heo와 Lee (2012)의 기준을, 발화는 Kim (1997)과 Owens (2010) 의 기준을 따랐다. 발화 구분 원칙은 Appendix 1에, 대화차례 정의 및 세부적인 구분 원칙은 Appendix 2에 제시하였다. 주제는 Park 등(2017)의 분석 기준을 참고하였으며, 측정기준은 Appendix 3에 첨부하였다. 추가적으로, 아동의 발화 중 '없어요, 끝이에요, 이게 다에요 등'의 대화를 종결한 경우는 주제 관리 능력 분석 시, 해당 대화차례를 제외하였다. 주제 관리 능력의 분석 방법은 아래와 같 고, 각각의 예시는 Appendix 4에 첨부하였다.

\section{대화참여 지표}

정해진 대화프로토콜 내에서 얼마나 대화에 참여하여 대화를 이어나갔는지 확인하기 위해 대화차례 수와 대화차례당 발화 빈도 로 나누어 측정하였다.

대화차례 수: 대화차례 수는 대상자가 말을 시작하여 대화상대 방이 말을 시작하기까지의 대화를 주고받은 빈도를 말하며, 정해 진 대화프로토콜이 완료되는 동안 대상자와 대화 상대방이 대화 를 주고받은 총 빈도로 측정하였다.
대화차례당 발화 빈도: 대상자가 대화 상대방과 한 번의 대화차 례에서 산출하는 발화의 빈도를 말하며, 아동의 총 발화수를 전체 대화차례 빈도로 나누어서 측정하였다.

대화주제 관리 지표

전체 주제 수: 주제란 대상자가 대화하는 동안 새롭게 주제를 개 시 및 변경하는 경우, 이전에 소개된 주제로 동일한 개념, 주제, 어 휘, 구성요소가 연결된 경우를 말하며, 대화 프로토콜이 완료되는 동안 연구자와 아동이 함께 다루었던 모든 주제를 전체 주제 수로 측정하였다.

주제당 대화차례 빈도: 주제당 대화차례 빈도는 대화프로토콜 이 완료되는 동안 대상자가 산출한 대화차례 빈도를 전체 주제 수 로 나누어 측정하였다.

전체 주제 개시율: 주제 개시는 대상자가 스스로 말을 시작하여 대화차례를 주고받게 되는 것으로 대화를 유도하기 위한 자료를 제 시했을 때 아동이 먼저 말을 한 경우로 하였다. 전체 주제 개시율은 아동이 주제를 개시한 총 수를 대화차례 총 수로 나누어 비율로 측 정하였다.

전체 주제 유지율: 주제 유지는 대상자가 대화 상대방의 질문이 나 내용에 반응하여 말을 중단하거나 방해하는 것 없이 관련된 내 용이나 정보를 첨가해 대화차례를 이어가는 경우이다. 전체 주제 유지율은 아동이 주제를 유지한 총 수를 대화차례 총 수로 나누어 비율로 측정하였다.

전체 주제 변경률: 주제 변경은 대상자가 주제를 이어가는 도중 이전 대화주제와 관련이 없거나 이전 발화에서 새로운 주제로 바 뀌는 경우이다. 전체 주제 변경률은 전체 주제를 변경한 총수를 대 화차례 총수로 나누어 비율로 측정하였다.

\section{신뢰도}

자료 분석에 대한 신뢰도를 검증하기 위해 '한림 대화.화용 평가 프로토콜(Lee \& Choi, 2017)'의 저자 중 1 인을 제 2 검사자로 선정하 였다. 신뢰도는 전체 수집된 자료의 $20 \%$ 를 무작위로 추출하여 독 립적으로 분석하였다. 신뢰도를 측정하는 방법은 제 1 검사자와 제 2 검사자가 일치한 반응의 수를 일치한 반응의 수와 일치하지 않은 반응의 수로 합하여 나눈 후 100 을 곱하여 산출하였다. 그 결과 신 뢰 수준은 $98.37 \%$ 로 측정되었다. 
Table 2. Results of turn-taking and frequency of utterance per turn according to age group

\begin{tabular}{lccccc}
\hline & Elementary school & Middle school & High school & $F$ & Tukey post hoc \\
\hline Number of turn-taking & $68.00(15.60)$ & $74.46(11.31)$ & $99.00(23.32)$ & $13.143^{* * *}$ & $H>E, M$ \\
Frequency of utterance per turn & $1.20(.18)$ & $1.33(.30)$ & $1.36(.16)$ & 2.065 & \\
\hline
\end{tabular}

Values are presented as mean (SD).

${ }^{* * *} p<.001$.

Table 3. Results of conversational topic manipulation according to age group

\begin{tabular}{|c|c|c|c|c|c|}
\hline & Elementary school & Middle school & High school & $F$ & Tukey post hoc \\
\hline Total number of topics & $16.33(4.45)$ & $13.46(1.76)$ & $10.80(1.26)$ & $14.046^{* * *}$ & $\mathrm{E}>\mathrm{M}>\mathrm{H}$ \\
\hline Frequency of turn per topic & $4.26(.79)$ & $5.57(.83)$ & $9.24(2.23)$ & $47.613^{* * *}$ & $\mathrm{H}>\mathrm{M}>\mathrm{E}$ \\
\hline Rate of initiation & $3.50(.93)$ & $2.78(.58)$ & $2.06(.68)$ & $13.822^{* * *}$ & $\mathrm{E}>\mathrm{M}>\mathrm{H}$ \\
\hline Rate of maintenance & $85.43(5.64)$ & $90.13(3.69)$ & $94.37(1.74)$ & $18.525^{* * *}$ & $\mathrm{H}>\mathrm{M}>\mathrm{E}$ \\
\hline Rate of change & $11.05(6.08)$ & 7.07 (3.25) & $3.28(1.73)$ & $13.432^{* * *}$ & $\mathrm{E}>\mathrm{M}>\mathrm{H}$ \\
\hline
\end{tabular}

Values are presented as mean (SD).

${ }^{* * *} p<.001$.

\section{통계처리}

자료의 통계처리는 주제운용능력의 초, 중, 고 집단 간 차이가 있 는지 알아보기 위해 일원배치분산분석(one-way ANOVA)과 Tukey 사후분석을 실시하였다. 통계분석에 사용한 프로그램은 SPSS version 22 이다.

\section{연구결과}

\section{연령에 따른 대화 참여 지표}

초등 고학년생, 중학생, 고등학생 집단의 대화 참여 지표 발달에 서의 차이를 확인하기 위해 대화차례 주고받기 수와 대화차례당 발화 빈도를 비교한 결과는 Table 2와 같다.

대화차례 주고받기 수는 집단 간 유의한 차이 $\left(F_{(2,42)}=13.143\right.$, $p<.001)$ 를 보였지만, 대화차례당 발화 빈도는 집단 간 유의미한 차 이를 보이지 않았다. 대화차례 주고받기 수의 집단 차이는 고등학 생 집단이 초등학생, 중학생 집단보다 대화차례 주고받기 수가 더 많았다.

\section{연령에 따른 대화 주제 관리 지표}

초등 고학년생, 중학생, 고등학생 집단의 대화 주제 관리 지표에 서의 차이를 확인하기 위해 전체 주제 수, 주제당 대화차례 빈도를 비교한 결과는 Table 3과 같다.

전체 주제 수 $\left(F_{(2,42)}=14.046, p<.001\right)$ 와 주제당 대화차례 빈도 $\left(F_{(2,42)}=47.613, p<.001\right)$ 모두 집단 간 유의미한 차이를 보였다. 전 체 주제 수의 집단 간 차이는 고등학생 집단이 초, 중학생 집단보다
더 적게 나타났고 중학생 집단은 초등학생 집단보다 더 적게 나타 났다. 주제당 대화차례 빈도의 집단 간 차이는 고등학생 집단이 초, 중학생 집단보다 높게 나타났고 중학생 집단이 초등학생 집단보다 높게 나타났다.

주제개시비율 $\left(F_{(2,42)}=13.822, p<.001\right)$, 주제유지비율 $\left(F_{(2,42)}=18.525\right.$, $p<.001)$ 과 주제변경비율 $\left(F_{(2,42)}=13.432, p<.001\right)$ 모두 집단 간 유 의미한 차이를 보였다. 주제개시비율과 주제변경비율의 집단 간 차 이는 고등학생 집단이 초, 중학생 집단보다 더 적게 나타났고 중학 생 집단이 초등학생 집단보다 더 적게 나타났다. 주제유지비율의 집단 간 차이는 고등학생 집단이 초, 중학생 집단보다 더 높게 나타 났고 중학생 집단이 초등학생 집단보다 더 높게 나타났다.

\section{논의 및 결론}

본 연구는 초등 고학년생, 중학생, 고등학생의 청소년을 대상으 로 대화 발달을 알아보고자 하였다. 대화의 참여 지표 측면을 살펴 보기 위해, 대화차례 총 수와 대화차례당 발화 빈도를 분석하였다. 대화차례 총수는 초, 중, 고 세 집단 간 유의미한 차이를 보였다. 이 는 연령이 높아질수록 더 적극적으로 대화에 참여하고 오랜 시간 동안 대화를 주고받으며 이어나간 것으로 볼 수 있다. $4,6,9$ 세의 일 반아동을 대상으로 대화 능력을 살펴본 Baines와 Howe (2010) 또 한, 연령이 증가할수록 대화차례 주고받는 빈도가 증가하였다고 보 고하였다. 따라서 대화차례 총 수는 청소년의 대화 발달 역량을 확 인해볼수 있는수치가 될 수 있다.

이에 반해, 대화차례당 발화 빈도는 초, 중, 고 세 집단 간 유의미 
한 차이가 없는 것으로 나타났다. 즉, 세 집단 모두 자신의 대화차례 가 주어졌을 때 비슷한 양의 발화로 말하며 대화를 이어나간다는 것이다. 그러나 학령기 아동을 대상으로 대화능력을 살펴본 선행 연구(Park et al., 2017)에서는 대화차례당 발화 빈도에서 집단 간 유의미한 차이가 나타났다. Lee와 Kim (2001)에 따르면, 대화차례 당 발화 빈도는 언어적 능력에 따라 달라질 수 있다고 하였다. 아동 기에 비해 청소년기는 언어능력이 일정 수준에 도달하므로 대화차 례당 발화 빈도에서는 차이를 보이지 않았을 수 있다. 또한 청소년 기 언어 표현 특성상 대체로 길게 표현하지 않고 짧은 발화로 대화 를 이어가기 때문에 나타난 결과일 수도 있다. 결론적으로 청소년 기는 대화차례당 발화 빈도에 비해 대화차례 수가 대화 참여 정도 를 민감하게 반영하는 것으로 해석할 수 있다.

대화 주제 관리 측면에서, 전체 주제 수는 초, 중, 고로 증가함에 따라 유의하게 감소한 반면 주제당 대화차례 빈도는 연령이 증가함 에 따라 유의하게 증가하였다. 이는 연령이 증가함에 따라 적은 수 의 주제로 더 긴 대화차례를 이어감을 보여준다. 학령기 아동을 대 상으로 한 Park 등 (2017)과 5세, 9세와 성인을 대상으로 한 Brinton 과 Fujiki (1984)도 동일한 결과를 보고하였다. 연령이 어릴수록 주 제를 더 많이 전환하는 데 반해, 연령이 증가할수록 한 주제 안에서 대화차례를 더 많이 가지면서 하나의 주제를 긴 시간 동안 유지해 나가는 것이다. 이러한 결과를 종합해보았을 때, 학령전기부터 청 소년기까지 연령이 증가함에 따라 한 주제 내에서 대화를 지속적으 로 주고받으며 이어나가는 능력이 발전된 것으로 해석할 수 있다.

대화 주제 관리를 주제개시, 주제유지, 주제변경으로 구분하여 살펴본 결과에서도 이러한 경향을 반영한다. 본 연구에서 초등학 생들은 중, 고등학생에 비해 주제개시와 주제변경 비율이 유의하게 높았으나 주제유지 비율은 유의하게 낮았다. 이는 초등학생들이 중, 고등학생에 비해 같은 주제로 대화를 지속하지 못하고 더 빈번 하게 대화 주제를 변경하거나 대화가 중단된 후 새로운 주제로 대 화를 개시하는 경향이 있음을 보여준다. 반대로, 중, 고등학생들은 초등학생들에 비해 같은 대화 주제로 대화를 유지하는 능력이 발 달되어 간다고 해석할 수 있다. 선행연구에 따르면 연령이 증가할수 록 주제와 관련된 발화 비율이 많아지고 새로운 정보를 적절하게 추가하여 대화를 유지하는 것으로 나타났다(Brinton \& Fujiki, 1984; Foster, 1985; Mentis, 1994; Schley \& Snow, 1992; Schober-Peterson \& Johnson, 1993).

본 연구결과를 종합하였을 때, 초, 중, 고등학생 간 대화차례 수는 유의미한 차이로 증가하였으나, 대화차례당 발화 빈도는 유의미한 차이가 없었다. 또한 연령이 증가할수록 대화 안에서 다루어지는 주제 수가 점차 적어지고 한 주제 안에서 많은 대화차례를 주고받
는 것으로 나타났으며, 연령이 증가할수록 주제를 개시하는 비율과 변경하는 비율이 적어지면서 적절하게 주제를 유지하는 비율이 증 가하였다. 본 연구의 결과는 청소년의 대화 발달을 잘 보여줄 수 있 는 지표로 대화차례 수, 전체 주제 수, 주제당 대화차례 빈도, 주제 유지, 주제변경을 제시할 수 있고, 청소년 집단 간 연령이 증가할수 록 대화능력이 발달하는 것으로 나타났다. 본 연구의 결과는 아동기 이후 청소년기까지도 대화 능력이 지속적으로 발달됨을 보여준다.

\section{REFERENCES}

Baines, E., \& Howe, C. (2010). Discourse topic management and discussion skills in middle childhood: the effects of age and task. Frist Language, 30, 508-534.

Brinton, B., \& Fujiki, M. (1984). Development of topic manipulation skills in discourse. Journal of Speech and Hearing Research, 27, 360-358.

Choi, J., \& Lee, Y. (2013). Conversational turn-taking and topic manipulation skills of children with high-functioning autism spectrum disorders. Communication Sciences \& Disorders, 18, 12-23.

Dodge, K. A. (1983). Behavioral antecedents of peer social status. Child Development, 54, 1386-1399.

Foster, S. (1985). The development of discourse topic skills by infants and young children. Topic in Language disorders, 5, 31-45.

Heo, H., \& Lee, Y. (2012). Conversational turn-taking and topic manipulation skills in conversations of school-age low-achievers in language learning. Korean Journal of Communication Disorders, 17, 66-78.

Kim, S. E., \& Lee, Y. (2007). Conversation characteristics of children with attention deficit hyperactivity disorder. Korean Journal of Communication Disorders, 12, 662-675.

Kim, Y. T. (1997). Foundation of length of utterance in 2 to 4 year-old children. Korean Journal of Communication Disorders, 2, 5-26.

Kim, Y. T., Hong, G. H., Kim, K. H., Jang, H. S., \& Lee, J. Y. (2009). Receptive \& expressive vocabulary test (REVT). Seoul: Seoul Community Rehabilitation Center.

Kwak, K. C., Oh, S. W., \& Kim C. T. (2011). Korean-Wechsler Intelligence Scale for Children-IV (K-WISC-IV). Seoul: Hakjisa.

Lee, H. J., \& Kim, Y. T. (2001). Turn-taking characteristics of children with specific language impairment and normal children. Korean Journal of Communication Disorders, 6, 293-312.

Lee, Y., \& Choi, J. (2017). Hallym Conversation and Pragmatic Assessment Protocol. Manuscript in preparation. 
Loban, W. (1976). Language development: kindergarten through grade twelve. Urbana, IL: National Council of Teachers of English.

Mentis, M. (1994). Topic management in discourse: assessment and intervention. Topics in Language Disorders, 14, 29-54.

Nippold, M. A. (2007). Later language development: school-age children, adolescents, and young adults. Austin, TX: Pro-Ed.

Owens, R, E. (2010). Language disorder: a functional approach to assessment and intervention (5th ed.). Boston, MA: Allyn \& Bacon.

Park, Y., Choi, J., \& Lee, Y. (2017). Development of topic management skills in conversation of school-aged children. Communication Sciences \& Disorders, 22, 25-34.

Sacks, H., Schegloff, E. A., \& Jefferson, G. (1974). A simplest systematics for the organization of turn-taking for conversation. Language, 50, 696-735.

Schley, S., \& Snow, C. (1992). The conversational skills of school-aged children. Social Development, 1, 18-35.

Schober-Peterson, D., \& Johnson, C. J. (1993). The performance of eight-to ten-year-olds on measures of conversational skilfulness. First Language, $13,249-269$ 
Appendix 1. 발화 구분 원칙

발화 구분 원칙

1. 1 문장 1 발화를 원칙으로 한다.

2. 시간의 경과(대략 5 초 이상)나 두드러진 운율의 변화, 주제의 변화가 있을 때는 발화 수를 나눈다.

3. 같은 말이라도 다른 상황이나 문맥에서 표현되거나, 새로운 의미로 표현되었을 때에는 다른 발화로 취급한다.

4. 아동이 스스로 수정하거나 새로운 의미의 첨가 없이 낱말이나 구를 반복할 때는 한 문장 안에 넣되 ( )로 구분하고 분석에서 제외시킨다.

5. 아이가 습관적으로 (샘플자료의 $10 \%$ 이상 발화) 사용하는 간투어는 분석에서 제외시킨다.

6. '아', '오' 등의 감탄하는 소리나 문장을 이어가기 위한 무의미 소리들 (예: 음, 어 등의 말이음)은 분석에서 제외시킨다.

7. 노래하기, 숫자세기 등과 같이 외워진 자동구어는 발화로 구분하지 않고 분석에서 제외시킨다. 그러나 발화 속에 이러한 자동구어가 내포 되어 있을 경우에는 하나의 낱말로 보고 분석에서 포함시킨다.

8. ‘그리고’나 연결어미 ‘'고’를 사용하여 계속 연결한 문장은 발화에 ‘그리 고' 또는 '-고'가 하나만 포함되도록 발화를 나눈다.
“카드게임 줘요.. 줘요"

$\rightarrow$ 카드게임 줘요 (발화1)

$\rightarrow$ 줘요 (발화 2)

(대상자가 핸드폰을 주머니에서 꺼내며)

“봐요" (발화 1)

(대상자가 핸드폰을 열고 보여주며)

“봐요" (발화 2)

"(이렇게) 몸을 이렇게 해보세요"

"어렸을 때 (어) 아빠랑 (어) 자전거 탔어"

“(아), 있다!”

"일, 이, 삼, 사, 오, 육, 칠"

"오늘밤 주인공은 나야나 나야나"

$\rightarrow$ 발화로 취급하지 않음

"이거 나야나 나오는 건데"

$\longrightarrow$ 발화로 취급하되, '나야나'는 하나의 낱말로 취급

"여행가서 제주도에서 조랑말도 타고 삼겹살도 먹고 흑돼지도 먹고 고기국수도 먹고 멸치

국수도 먹고 열차도 타고 산도 타고 놀았어요."

0. 여행가서 제주도에서 조랑말도 타고 삼겹살도 먹고

1. (그리고)흑돼지도 먹고 고기 국수도 먹고

2. (그리고)멸치국수도 먹고 열차도 타고

3. (그리고)산도 타고 놀았어요.

Kim (1997), Owens (2010).

Appendix 2. 대화차례 정의 및 세부적인 구분 원칙

\begin{tabular}{|c|c|}
\hline 구분 & 예 \\
\hline $\begin{array}{l}\text { 1. 대화차례는 화자가 말을 시작하여 대화상대자가 말을 시작하기 전까지 } \\
\text { 동일한 화자가 이어간 모든 발화를 의미한다. }\end{array}$ & $\begin{array}{l}\text { 검: "가족들하고 여행 가서는 뭐해?" } \\
\text { 아: "가족들이랑 고기 구워먹거나 어디 가서 보거나 사진 찍어요." } \\
\text { 검: “고기 구워먹거나 어디 가서 보거나 사진 찍는구나.” }\end{array}$ \\
\hline $\begin{array}{l}\text { 2. 아동이 자신이 말 차례에 대화 주제를 변경하는 경우 대화차례를 } \\
\text { 나눈다. }\end{array}$ & $\begin{array}{l}\text { 성인: “점심 시간에는 뭐해" } \\
\text { 아동: "점심시간에는 밥 먹고 애들이랑 같이 올라오고요." (대화차례 1) } \\
\text { 아동: “쉬는 시간에는 아이돌 애기하든가 그냥 같이 다니고 막 그래요." (대화차례 2) }\end{array}$ \\
\hline $\begin{array}{l}\text { 3. 동일한 주제로 대화차례를 이어나갈 때, 발화 중에 3초 이상 쉼이 나타 } \\
\text { 나는 경우에는 서로 다른 대화차례로 구분한다. }\end{array}$ & $\begin{array}{l}\text { 성인: "요즘 너랑 친구들은 뭐를 좋아해” } \\
\text { 아동: "먹는 거 좋아하고 게임 하는 거 좋아해요. (3”)" } \\
\text { 아동: “그 다음에 좋아하는 거 없는데." }\end{array}$ \\
\hline $\begin{array}{l}\text { 4. 아동이 자신의 대화차례에서 맞장구(back channel responses) 등의 } \\
\text { 낱말이나 구로 말한 경우에도 하나의 대화차례로 인정한다. }\end{array}$ & $\begin{array}{l}\text { 아동: "저 떡볶이 좋아해요." } \\
\text { 성인: "떡볶이 좋아하는구나." } \\
\text { 아동: "맞아요" }\end{array}$ \\
\hline $\begin{array}{l}\text { 5. 아동이 단순히 상대방의 말을 듣고 있다는 추임새로서 머리 끄덕이기, } \\
\text { 고개 젓기, 가리키기 등의 비구어적 행동은 대화차례로 보지 않으나, 대 } \\
\text { 화 상대방의 질문이나 지시에 자연스럽게 상대방에게 대화차례를 넘기 } \\
\text { 는 기능(turn passing-move function)을 가지는 발성 및 행동의 경우 } \\
\text { 에는 하나의 대화차례로 간주한다. }\end{array}$ & $\begin{array}{l}\text { 아동: “친구들 만나면 노래방 가서 노래 부르고 놀이터에서 얼음 땡하고." } \\
\text { 성인: “친구들 만나면 노래방 가고 놀이터에서 얼음 땡하고. (3초 후) 그리고” } \\
\text { 아동: (고개를 가로로 저음) } \\
\text { 성인: “이제 없어, 알겠어." }\end{array}$ \\
\hline
\end{tabular}

Heo \& Lee (2012) 재수정. 
Appendix 3. 주제 정의 및 세부구분 원칙

1. 주제란 대화의 단위로 서로 연관된 일련의 발화로 이루어진다(Schober-Peterson \& Johnson, 1993).

2. 새롭게 주제를 개시하거나 변경하는 경우, 이미 소개된 주제로 동일한 어휘, 동일한 주제어(theme), 동일한 개념(concept) 또는 구성요소로 연결된 경우를 하나의 주제로 한다(Schober-Peterson \& Johnson, 1993).

\section{주제 측정의 구체적인 정의는 다음과 같다.}

구분

예

1. 새롭게 주제가 개시된 후 새로운 주제로 변경되기 전까지 이어진 발화는 하나의 주제로 측정한다.

2. 소개된 주제를 정교화하거나 내용을 첨가하는 경우에도 발화들이 서로 연관되 는 경우는 하나의 주제로 측정한다.

3. 하나의 주제가 종료되고 다른 주제로 변경되었다가 다시 이전 주제로 달라진 경 우에도 새로운 주제로 측정하지 않는다.

아동: "저희가 이제 고등학생이잖아요. 고등학생 애들은 이제 한창 먹는 걸 좋아 할 시기에요." (주제1: 학교급식)

성인: "한창 먹을 걸 좋아할 시기이구나."

아동: “그래서 경기도를 예로 그니까 저희 지역 남양주시를 예를 들어보면 급식

이 되게 안 좋아요."(정교화 및 내용 첨가)

성인: "아, 급식이 안 좋구나."

아동: "네 그리고 제가 수련회를 갔었어요." (주제2로 변경)

성인: "아, 수련회를 갔었어."

아동: "네 아 근데 정말 너무 어이가 없었던 게 아까 급식이요. 영양사 선생님이 바겼는데도 맛이 없어요." (주제1을 다시 소개한 경우, 새로운 주제 도입하 지 않음)

Park, Choi, \& Lee (2017)

Appendix 4. 주제 관리 능력의 유형(주제개시, 주제유지, 주제변경)별 정의 및 예시

\begin{tabular}{|c|c|c|}
\hline 구분 & 정의 & 예시 \\
\hline 제개시 & $\begin{array}{l}\text { 이전 주제가 종료된 후, 제시된 사진자료와 관련한 주제로 } \\
\text { 대화차례를 먼저 자발적으로 도입한 경우 혹은 이전에 } \\
\text { 개시된 주제를 다시 말한 경우에 주제개시로 정의하였다. }\end{array}$ & $\begin{array}{l}\text { 성인: "자, 우리 이제 대화 시작해볼까" } \\
\text { 아동: "엄마랑 아빠랑 저랑 가족여행으로 영국에 갔었는데." }\end{array}$ \\
\hline 제유지 & $\begin{array}{l}\text { 이전 대화차례 과정에서 개시된 주제와 관련한 내용 반복, } \\
\text { 간단한 정보나 구체적인 의미를 추가하여 대화차례를 } \\
\text { 이어나가는 경우에 주제유지로 정의하였다. } \\
\text { (1) 어휘로 연결된 경우 } \\
\text { (2) 주제(theme)로 연결된 경우 } \\
\text { (3) 개념(concept)이나 구성요소로 연결된 경우 }\end{array}$ & 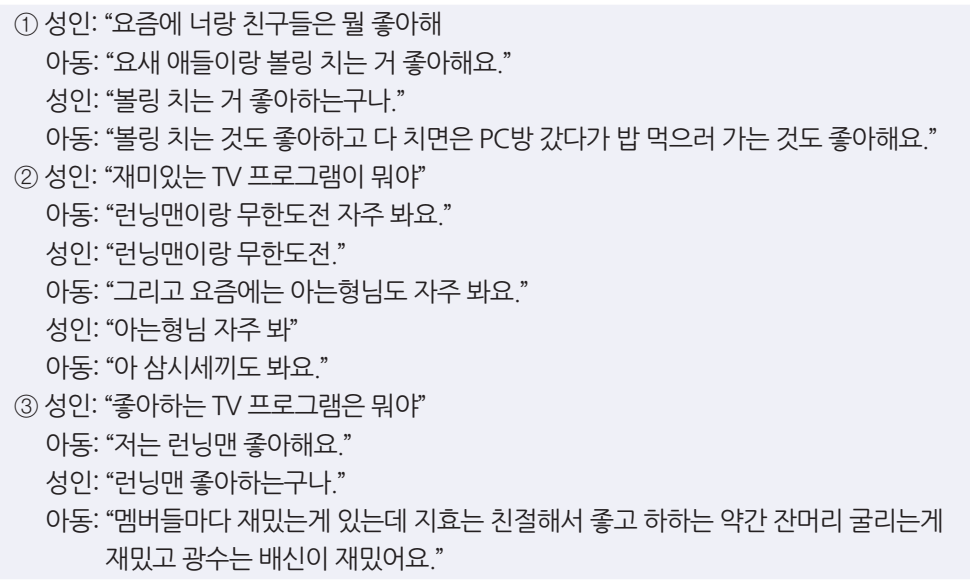 \\
\hline 제변경 & $\begin{array}{l}\text { 이전 대화차례를 이어가는 도중, 주제와 관련되지 않거나 } \\
\text { 이전 발화에서 등장하지 않은 새로운 주제로 대화의 } \\
\text { 주제가 바뀌는 경우에 주제변경으로 정의하였다. }\end{array}$ & $\begin{array}{l}\text { 아동: "저희 반에 친구가 한 네 다섯 명이 있는데요. 점심 먹을 때 같이 이야기 나누고 그래요." } \\
\text { 성인: "점심에 모여서 이야기 나누고 그러는구나." } \\
\text { 아동: "그리고 현장학습 때요. 무슨 롯데월드 같은 데 가서 다니면서 뭐 사먹고 그러다가 싸우 } \\
\quad \text { 고 다시 친해졌어요." (주제 변경) }\end{array}$ \\
\hline
\end{tabular}

Choi \& Lee (2013) 재수정. 


\section{국문초록}

\section{후기 아동기에서 청소년기까지의 대화발달}

양예원 ${ }^{1}$ 이윤경 $\cdot$ 최지은 ${ }^{3}$ 윤지혜 ${ }^{2}$

'한림대학교 보건과학대학원 언어병리학과, ${ }^{2}$ 한림대학교 언어청각학부, ${ }^{3}$ 한림대학교 대학원 언어병리청각학과

배경 및 목적: 본 연구는 청소년을 대상으로 연령에 따른 대화 주제운용능력의 발달 차이를 살펴보았다. 방법: 연구대상은 초등 고학 년생, 중학생, 고등학생 각 15 명씩 총 45 명이다. 대상자에게 한림 대화-화용 평가프로토콜에 따라 대화 자료를 수집하고 대화차례 수, 대화차례당 발화 빈도, 전체 주제 수, 주제당 대화차례 빈도, 주제 개시 비율, 주제 유지 비율 주제 변경 비율을 측정하였다. 결과: 대화차 례 주고받기 수는 집단 간 유의한 차이가 있었으나 대화차례당 발화빈도는 유의한 차이가 없었다. 전체 주제 수, 주제당 대화차례 빈도 는 집단 간 유의한 차이가 있었고, 주제 개시 비율, 주제 유지 비율, 주제 변경 비율 모두 집단 간 유의한 차이가 나타났다. 논의 및 결론: 청소년은 연령이 증가할수록 대화차례 수가 많아지고 대화 안에서 다루어지는 주제 수가 점차 감소하며 한 주제 안에서 더 많은 대화차 례를 주고받는 것으로 나타났다. 연령이 증가할수록 주제를 변경하지 않고 한 주제를 일관되게 유지하며 대화를 이어나갔다. 이러한 결 과는 청소년의 대화 발달을 이해하는 데 도움을 준다.

핵심어: 청소년기, 대화 발달, 주제운용

본 논문은 제 1 저자의 석사학위논문(2018)의 일부를 발췌한 것임.

본 논문은 2017년도 한림 선도연구그룹지원사업(No. HRF-LGR-2017-0002)의 지원을 받아 연구되었음.

\section{참고문헌}

곽금주, 오상우, 김청택(2011). 한국판 웩슬러 아동용 지능검사(K-WISC-IV). 서울: 학지사. 김성은, 이윤경(2007). 주의력결핍 과잉행동장애(ADHD) 아동의 말 차례 주고받기 특성. 언어청각장애연구, 12, 662-675 김영태(1997). 한국 2-4 세 아동의 발화길이에 관한 기초연구. 말-언어장애연구, 2, 5-26. 김영태, 홍경훈, 김경희, 장혜성, 이주연(2009). 수용·표현어휘력검사(REVT). 서울: 서울장애인종합복지관. 박윤정, 최지은, 이윤경(2017). 초등학생 아동의 대화 화제관리 능력의 발달. 언어청각장애연구, 22, 25-34. 이효진, 김영태(2001). 단순언어장애 아동의 대화 말 차례 특성. 언어청각장애연구, 6, 293-312. 최지은, 이윤경(2013). 학령기 고기능 자폐범주성장애 아동의 대화차례 주고받기 및 주제운용능력. 언어청각장애연구, 18, 12-23. 허현숙, 이윤경(2012). 언어학습부진아동의 대화차례 주고받기 및 주제운용 특성. 언어청각장애연구, 17, 66-78. 